\title{
Treba li redefinirati fiskalne kriterije iz Maastrichta?
}

\author{
ANTO BAJO, Institut za javne financije \\ MARKO PRIMORAC, Ekonomski fakultet Zagreb
}

Statistički ured Europske komisije - Eurostat - je početkom veljače 2015. prvi puta objavio podatke o potencijalnim obvezama i "lošim kreditima" država članica Europske unije (EU). Potencijalne obveze uključuju jamstva, obveze povezane s projektima javno-privatnog partnerstva i obveze javnih poduzeća koja su pod kontrolom države, ali nisu u statističkom obuhvatu opće države. Visina potencijalnih obveza država članica otkriva znatno drugačiju sliku njihove zaduženosti, izloženosti fiskalnim rizicima i otvara pitanje o potrebi redefiniranja fiskalnih kriterija iz Maastrichta. Očito je da države članice pod pritiskom proračunskih ograničenja (u skladu s kriterijima iz Maastrichta) kreiraju obveze koje utječu na rast javnog duga, a koje su do nedavno bile izvan dosega Eurostata.

\section{UvOD}

Radi zaobilaženja fiskalnih kriterija iz Maastrichta i pod utjecajem financijske krize, države članice EU-a kreiraju potencijalne obveze koje se vode izvanbilančno. S obzirom da ne utječu na razinu duga i deficita opće države, te su obveze do sada uglavnom prolazile nezapaženo. U studenome 20II. Europski Parlament i Europsko Vijeće usvojili su Poboljšani okvir za upravljanje ekonomskom politikom u EU-u (engl. Enhanced Economic Governance Package - popularno nazvan Six-pack), koji se sastoji od Direktive Vijeća 2OII/85/EU i pet uredbi. Među ostalim statističkim zahtjevima, Poboljšanim okvirom je propisano i prikupljanje podataka o potencijalnim obvezama, dok Direktiva 2II/85/EU propisuje obvezu objave informacija o potencijalnim obvezama svih podsektora opće države. Eurostat traži od država članica izvještavanje o visini i strukturi jamstava, loših kredita, obveza iz projekata javno-privatnog partnerstva (JPP) $i$ obveza javnih poduzeća. Podatke o potencijalnim obvezama nacionalni statistički zavodi dostavljaju Eurostatu godišnje (prije 3I. prosinca) za prethodnu godinu. Prva isporuka podataka počela je 20I4. za 2013., a Eurostat je u siječnju 20I5. objavio prve nepotpune podatke po državama članicama (vidi prilog). Analiza visine i strukture potencijalnih obveza otkriva realniji obujam fiskalnih rizika i pruža nešto drugačiju sliku fiskalne pozicije država članica.

\footnotetext{
${ }^{\mathrm{I}}$ Uredba br. II73/20II o učinkovitoj provedbi proračunskog nadzora u europodručju, Uredba br. II74/20II o provedbenim mjerama za ispravljanje prekomjernih makroekonomskih neravnoteža u europodručju, Uredba II75/2OII o izmjeni Uredbe br. I466/97 o jačanju nadzora stanja proračuna i nadzora i koordinacije ekonomskih politika, Uredba br. II76/20II o sprečavanju i ispravljanju makroekonomskih neravnoteža i Uredba br. II77/20II o izmjeni Uredbe br.I467/97 o ubrzanju i pojašnjenju provedbe postupka u slučaju prekomjernog deficita."
} 


\section{IZRAVNI DUG I PROGEDURA PREKOMJERNOG PRORAǦUNSKOG DEFICITA}

Procjena fiskalne (ne)stabilnosti država članica donedavno se temeljila isključivo na analizi izravnog duga i proračunskog deficita opće države. Tako su i kriteriji Pakta o stabilnosti i rastu, odnosno kriteriji iz Maastrichta, usmjereni na poštivanje limita (maksimalnih vrijednosti) udjela duga (60\%) i deficita konsolidiranog proračuna opće države (3\%) u BDP-u. Pojavom financijske krize, sve je manje država udovoljavalo utvrđenim fiskalnim kriterijima, pa su ušle u proceduru prekomjernog proračunskog deficita (PPPD). Trenutačno se u PPPD-u nalazi jedanaest država (Hrvatska, Malta, Cipar, Portugal, Slovenija, Poljska, Francuska, Irska, Grčka, Španjolska i UK), a u njemu su neko vrijeme bile gotovo sve države članice, osim Estonije i Švedske.

\section{Grafikon I.}

Dug opće države zemalja članica EU-a, 2013. (u \% BDP-a)

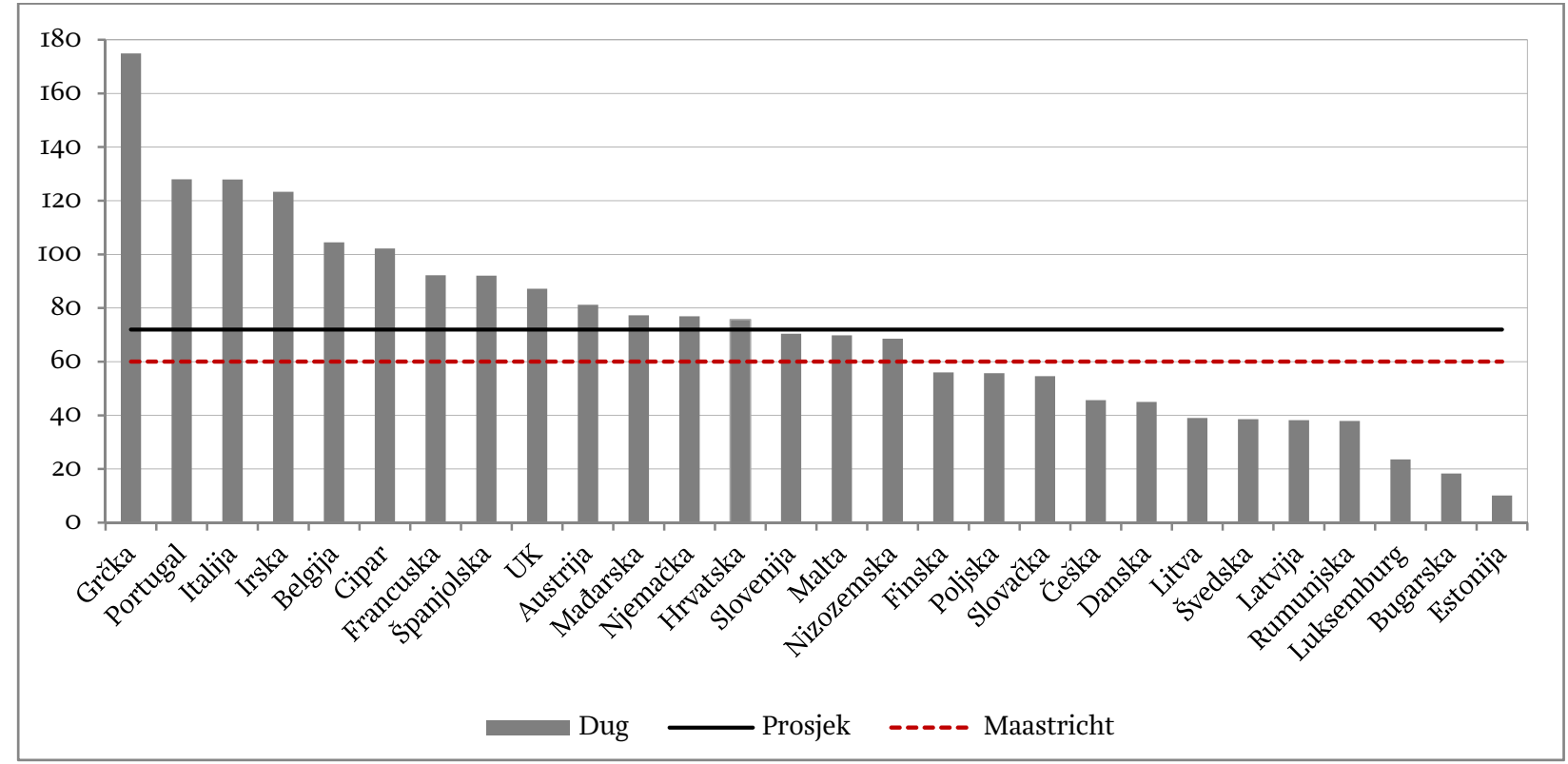

Izvor: Eurostat

\section{Grafikon 2.}

Saldo proračuna opće države u 2013. (u \% BDP-a)

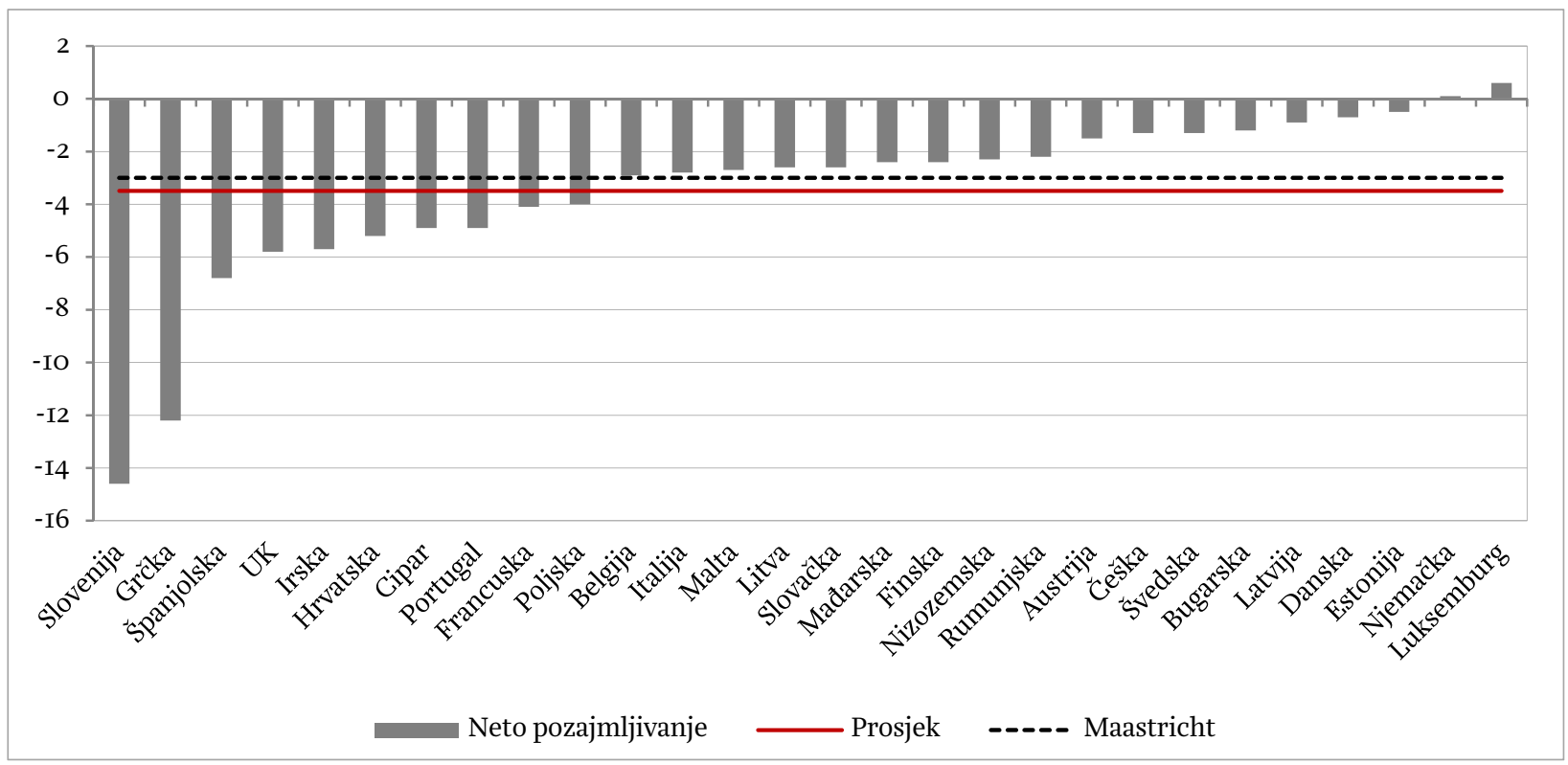

Izvor: Eurostat 
U 20I3. prosječan udio duga u BDP-u je 72\%, a Hrvatska je s dugom od 75,7\% BDP natprosječno zadužena članica. Od 28 država, njih I6 imalo je dug veći od 60\% BDP-a. Kriterij visine proračunskog deficita poštivao je veći broj država. Prosječna razina deficita u 2013. je 3,5\% BDP-a, a samo deset država imalo je deficit veći od 3\% BDP-a. Najveći deficit u 20I3. bilježi Slovenija (I4,6\%), a samo je Luksemburg ostvario suficit od o,6\% BDP-a.

Podaci o dugu i deficitu uglavnom se koriste kao pokazatelji fiskalnog položaja države. Međutim, države članice podložne su utjecaju potencijalnih obveza, loših kredita i rizika dospijeća dijela obveza koje država jamči u ugovorima JPP-a i njihovu pretvaranju u javni dug (izravne obveze). Stoga je opravdano pitanje treba li redefinirati kriterije iz Pakta o stabilnosti i rastu te u obuhvat duga uključiti potencijalne obveze. Te su obveze izvan bilance države, pa često nisu u fokusu javnosti i državnih politika.

\section{Potencijalne ObVeze}

Potencijalne obveze jesu: jamstva, projekti JPP-a, obveze javnih poduzeća i loši krediti. One ne ulaze u obuhvat duga opće države prema Smjernicama za primjenu Protokola o proceduri prekomjernog proračunskog deficita priloženog Sporazumu o osnivanju Europske zajednice - Council Regulation (EC) No 479/2009.

Jamstva su potencijalne obveze, jer davatelj jamči vjerovniku da će mu nadoknaditi štetu koju bi pretrpio kada bi izvorni dužnik prestao otplaćivati dug. Eurostat prikuplja podatke o standardiziranim i nestandardiziranim jamstvima. ${ }^{\mathrm{T}}$

\section{Grafikon 3.}

Jamstva opće države zemalja članica EU-a, 20I3. (u \% BDP-a)

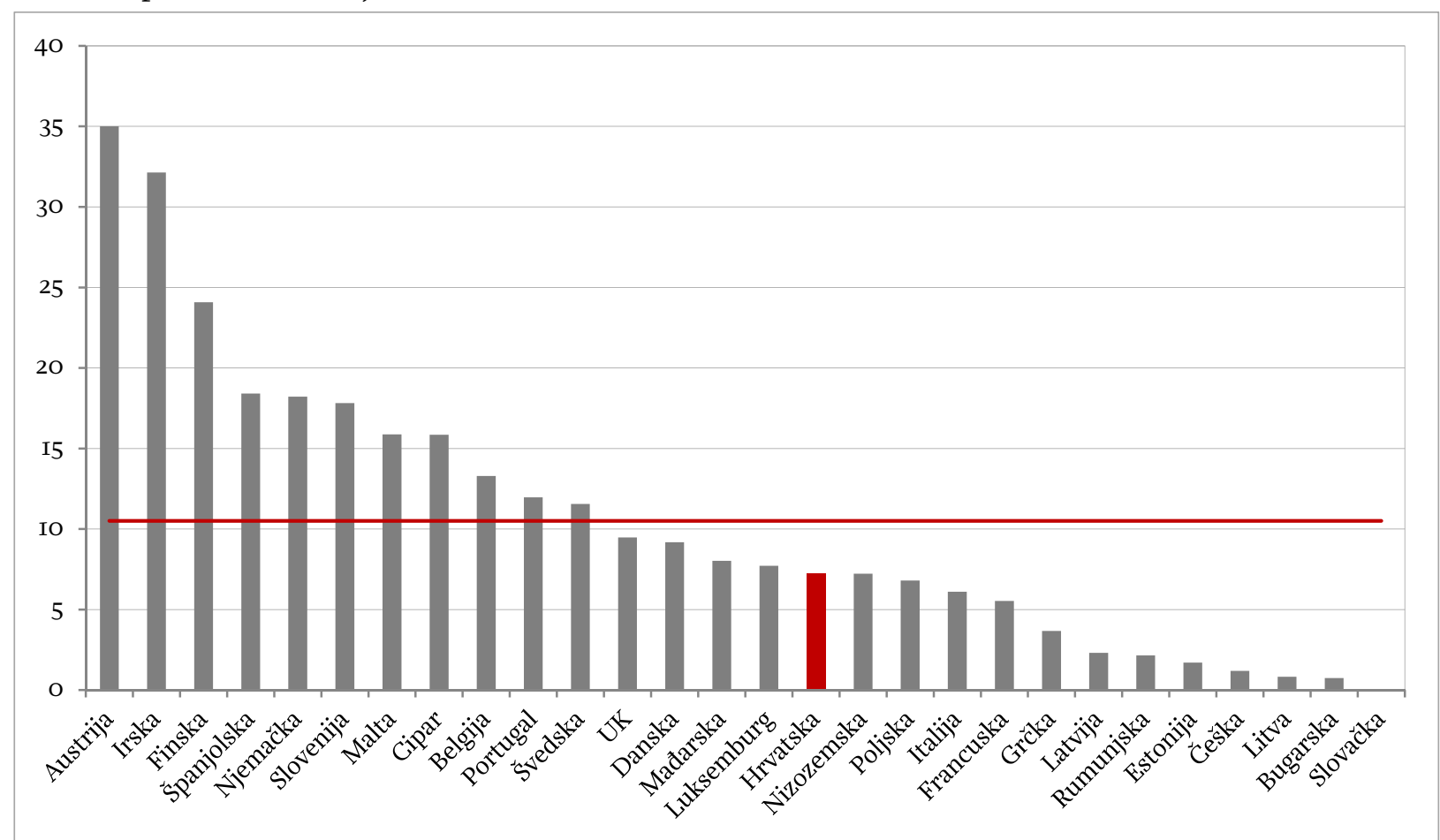

Izvor: Eurostat

\footnotetext{
${ }^{1}$ Nestandardizirana jamstva (engl. one-off) utvrđuju se pojedinačno i jamac nije u mogućnosti pouzdano procijeniti rizik protesta. Povezana su s instrumentima duga (kreditima i obveznicama). Standardizirana jamstva (engl. standardised) se izdaju u velikom broju uglavnom za znatno manje iznose, putem identičnih linija i uvjeta. Ni u okviru standardiziranih jamstava nije moguće precizno procijeniti rizik protesta za svaku kreditnu partiju, ali je moguće procijeniti koliko će - od većeg broja kredita - završiti protestom jamstava. Primjer standardiziranih jamstava su jamstva za stambene i studentske kredite, a nestandardiziranih - jamstva za obveze pojedinih javnih poduzeća.
} 
Najveći udio jamstava u BDP-u 20I3. imala je Austrija (35\%), a najmanji Slovačka (o,o3\%). Aktivna jamstva u Hrvatskoj čine 7,25\% BDP-a² (manja su od prosjeka EU-a koji iznosi IO,5\% BDP-a). Jamstva protestom prelaze iz kategorije potencijalnog u izravni javni dug.

Obveze javnih poduzeća klasificiranih izvan obuhvata opće države utvrđuju se krajem godine temeljem financijskih izvještaja. Ta su poduzeća (iako pod kontrolom države) klasificirana izvan sektora opće države jer posluju po tržišnim načelima (kao tržišni subjekti). Međutim, zbog kontrole koju ima nad poduzećima, izvjesno je da bi država preuzela njihove obveze ukoliko zapadnu u financijske poteškoće. Štoviše, države često pomažu takvim poduzećima izravnim transferima iz državnog proračuna. Naravno, sposobnost preuzimanja obveza na teret države izravno ovisi o gospodarskoj snazi pojedine države članice EU-a. Primjerice, problem sa stečajevima velikih trgovačkih društava lakše se rješava u državama s višim, u odnosu na one s niskim ili ispodprosječnim razinama BDP-a.

\section{Grafikon 4.}

Ukupan dug subjekata koje kontroliraju države članice, a klasificiran je izvan sektora opće države, 2013. (u \% BDP-a)

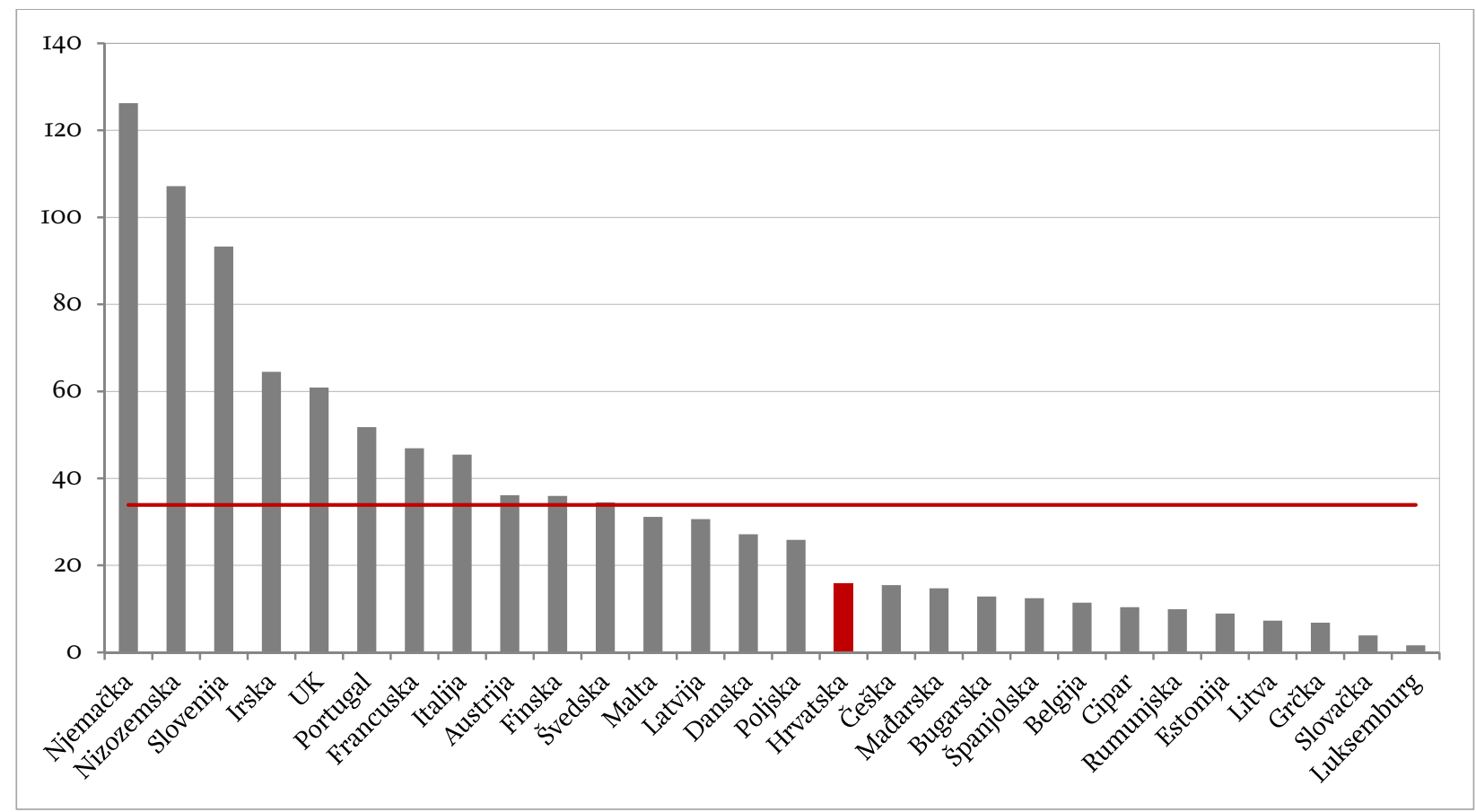

Napomena: Podaci za Njemačku, Cipar i Grčku odnose se na 2012. Izvor: Eurostat

Prosječan udio obveza javnih poduzeća izvan obuhvata opće države bio je gotovo 34\% BDP-a (od I26,3\% BDP-a u Njemačkoj do I,6\% BDP-a u Luksemburgu). Visoke obveze javnih poduzeća u vlasništvu države ukazuju da Europska komisija treba postupno širiti obuhvat javnog duga na sve institucije javnog sektora, a ne samo na obveze proračuna opće države.

Pojedine države imaju značajnu vrijednost financijske imovine (dionica i udjela) u javnim poduzećima i financijskim institucijama. Stoga je opravdano uspoređivati vrijednost financijske imovine s financijskim obvezama i izračunavati ukupne neto financijske obveze države kao vjerodostojniji pokazatelj fiskalnog položaja. ${ }^{3}$

\footnotetext{
${ }^{2}$ To je rezultat pretvaranja državnih jamstava brodogradilištima, Hrvatskim autocestama i Autocesti Rijeka-Zagreb u izravne obveze države. Smanjenja potencijalnih obveza utjecala su na rast izravnih obveza države.

${ }^{3}$ Financijskoj imovini države biti će posvećen jedan od idućih tekstova.
} 
Javno-privatno partnerstvo. Fiskalni rizici za državu proizlaze i iz potencijalnih obveza povezanih s JPP projektima. JPP označava dugoročne ugovorne odnose između poduzeća (ili skupine poduzeća) i tijela javne vlasti (države). Obveze iz ugovora o JPP-u evidentiraju se izvan bilance, a ukupne neotplaćene obveze JPP-a iskazuju se u prilagođenoj vrijednosti kapitala koja odražava utjecaj na dug u slučaju da država mora preuzeti imovinu tijekom trajanja ugovora. JPP projekti primjenjuju se u izgradnji i održavanju infrastrukturnih objekata, no države članice ih nisu prekomjerno koristile i tek u malobrojnima predstavljaju značajniji fiskalni rizik. Tako u Portugalu i Cipru JPP projekti u 20I3. čine oko 5\%, a u Irskoj, Mađarskoj, UK i Slovačkoj između I i 3\% BDP-a. U financiranju kapitalnih projekata Njemačka se značajno koristi JPP-om, ${ }^{4}$ ali je ujedno i jedina država članica za koju podaci o JPP-u nisu dostupni.

\section{Grafikon 5.}

Prilagođena vrijednost kapitala projekata javno-privatnog partnerstva zemalja članica EU-a izvan bilance, 20I3. (u \% BDP-a)

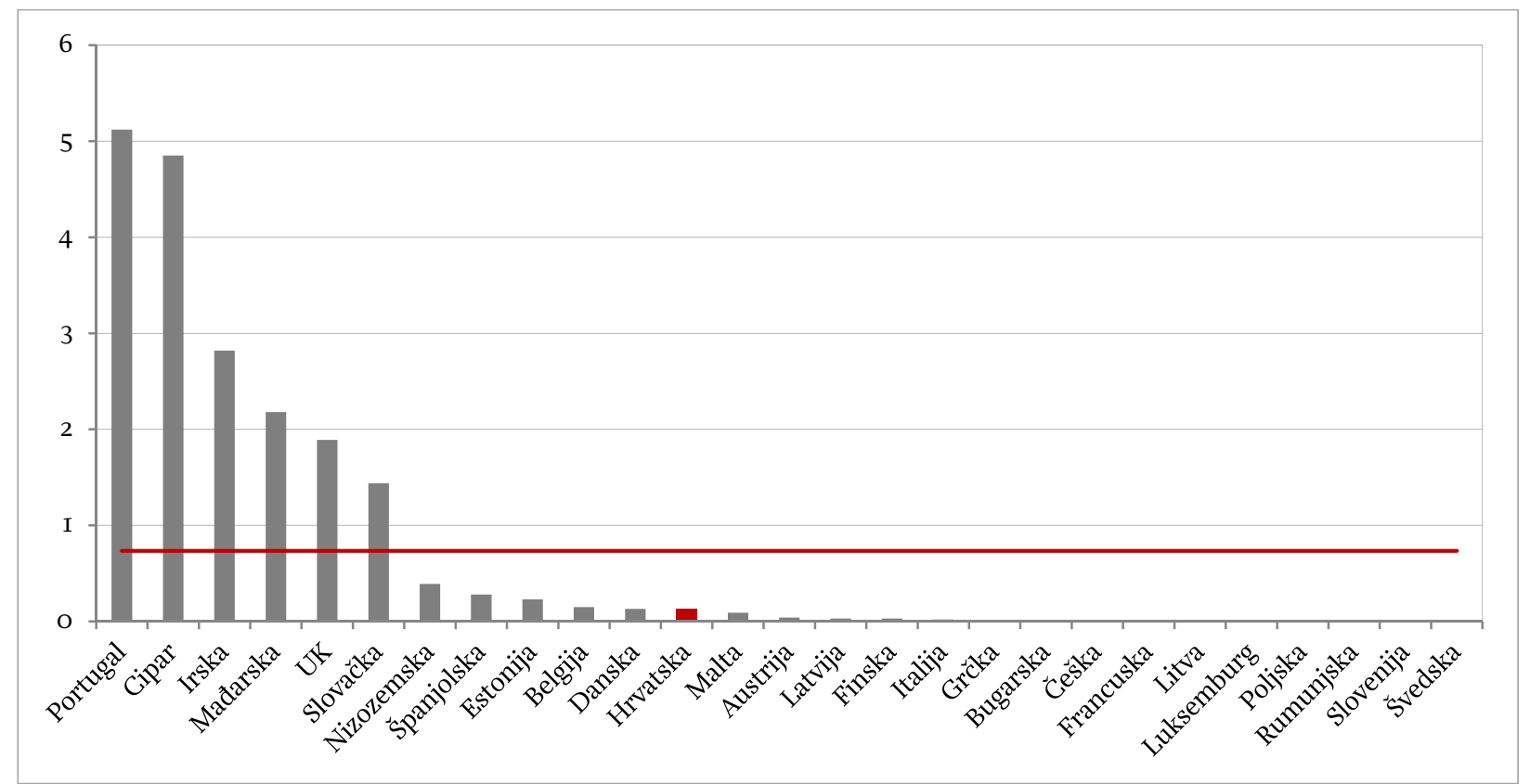

Izvor: Eurostat

Loši krediti (engl. non-performing loans) predstavljaju potencijalnu opasnost za državne financije ukoliko se dužnici koje je država kreditirala suoče s poteškoćama u otplati kredita. Riječ je o kreditima koje država daje subjektima izvan javnog sektora (primjerice, studentski krediti). Krediti se obično karakteriziraju kao "loši” ako otplata kamate ili glavnice kasni go i više dana, ili se temeljem drugih kriterija klasificiraju u tu skupinu (kamate za 90 i više dana se kapitaliziraju, refinanciraju, ili se odgađa njihovo plaćanje). Može se dogoditi i da nije ispunjen taj kriterij (kašnjenje u plaćanju 9o dana i duže), ali postoje drugi objektivni razlozi sumnje u mogućnost cjelovitog pridržavanja ugovornih obveza (na primjer, stečaj dužnika).

Značajan iznos loših kredita (veći od I\% BDP-a) prisutan je u Irskoj, Sloveniji i Portugalu, pri čemu je udio loših kredita od II,4\% BDP-a ozbiljno ugrožavao stabilnost irskih državnih financija. Te se obveze najvećim dijelom odnose na državnu Irish Bank Resolution Corporation (IBRC) koja je 20II. uključena u obuhvat opće države. Slično je i u Sloveniji gdje se većina loših kredita odnosi na kredite Družbe za upravljanje terjatev bank (DUTB) - državne institucije osnovane s ciljem sanacije loše (nenaplative) aktive slovenskih državnih banaka. Valja napomenuti da su brojne države članice EU-a tijekom financijske krize bile izložene rizicima poslovanja banaka. Države su te banke sanirale ili njihove obveze pretvarale u vlasničke udjele. Do 20I5. Hrvatska je jedna od rijetkih država koja nije imala problema s potencijalnim obvezama banaka, nego se uglavnom suočavala s obvezama brodogradilišta čija sanacija u razdoblju od 1992. do 2017. košta čak 30,6 mlrd. kuna (28,3 mlrd. od 1992. do 2012. i 2,3 mlrd. kuna od 2013. do 2017.)

${ }^{4}$ Vidi: Bundesministerium der Finanzen (2008). 


\section{Grafikon 6.}

Stanje kredita opće države zemalja članica EU-a koji se ne mogu naplatiti, 20I3. (u \% BDP-a)

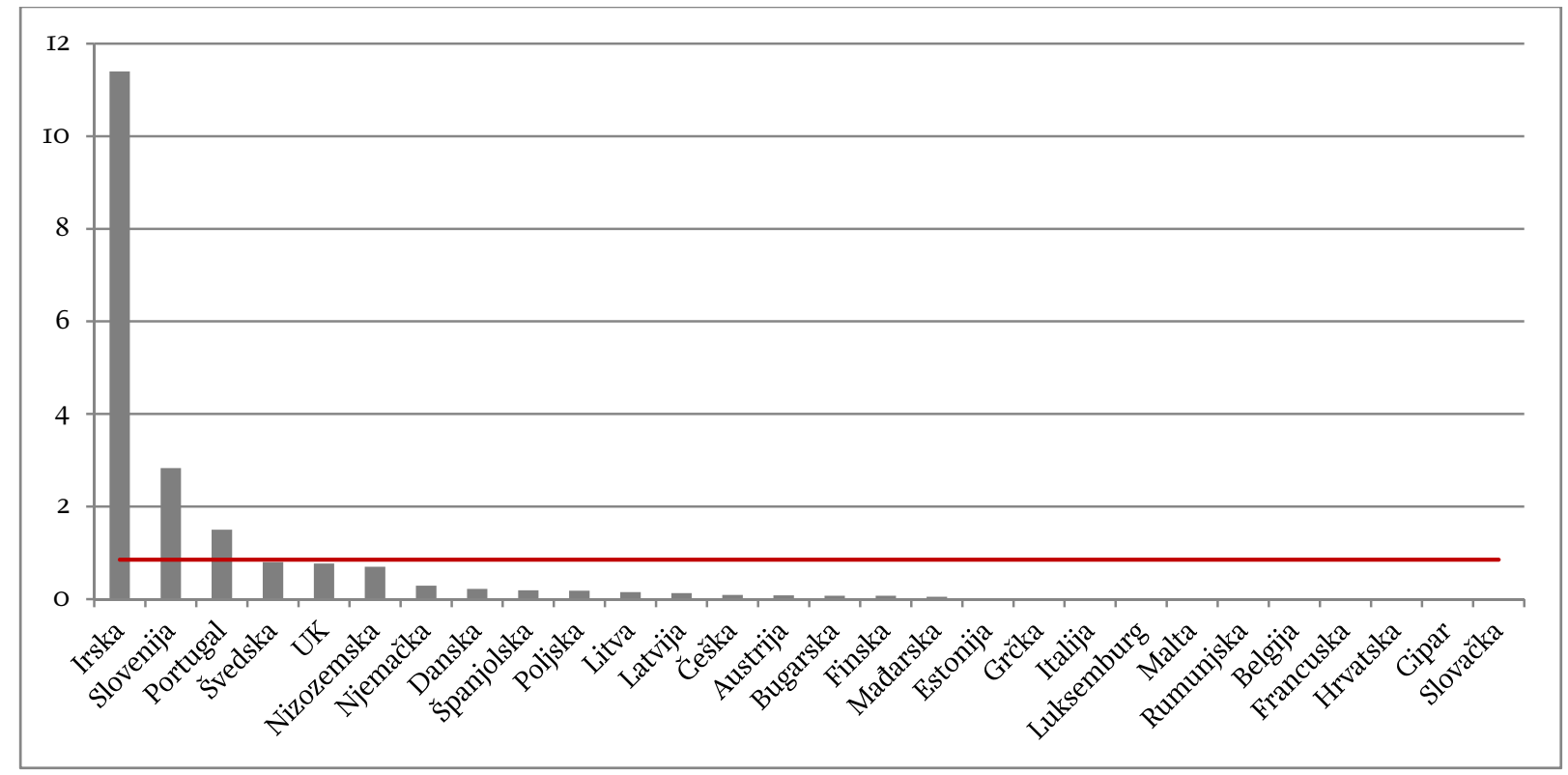

Izvor: Eurostat

\section{Grafikon 7.}

Ukupne potencijalne obveze zemalja članica EU-a, 20I3. (u \% BDP-a)

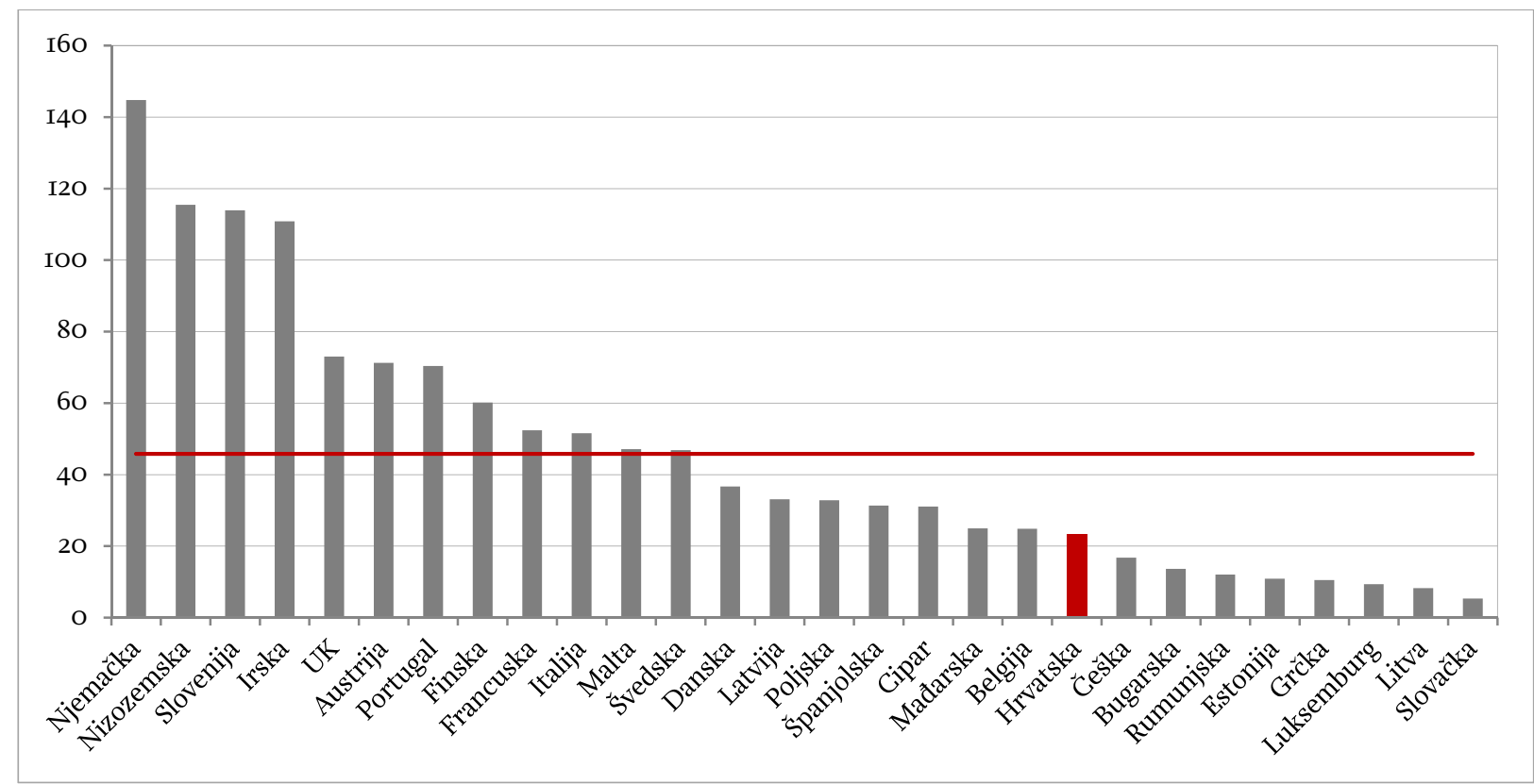

Izvor: Eurostat

Ukupne potencijalne obveze država članica su značajne i 2013. su u prosjeku iznosile oko 46\% BDP-a. Najveće su bile u Njemačkoj (gotovo I45\% BDP-a), a najmanje u Slovačkoj (nešto više od 5\% BDP-a). Hrvatska je 20I3. bila izložena potencijalnim obvezama u iznosu od oko 23\% BDP-a što je daleko ispod prosjeka EU-a. Međutim, udio duga (kako izravnog, tako i neizravnog) u BDP-u nije jedini kriterij za ocjenu financijske stabilnosti zemlje. Dapače, u nekim je državama javni dug znatno veći od BDP-a, što ne utječe na njihovu financijsku stabilnost (npr. Japan). S druge strane, u nekim državama s nižim razinama BDP-a, čak i niže razine duga mogu uzrokovati ozbiljne poteškoće u njegovoj otplati (npr. Hrvatska, Slovenija itd.). 


\section{UKUPNI (IZRAVNI I POTENCIJALNI) DUG DRŽAVA ČLANICA}

Podaci o ukupnom - izravnom i potencijalnom - dugu otkrivaju stvarnu sliku "fiskalne ranjivosti" država. Prosjek ukupnih obveza u BDP-u država članica 20I3. bio je oko II8\% BDP-a. Samo nekoliko država Slovačka, Rumunjska, Litva, Luksemburg, Bugarska i Estonija - zadovoljilo je i sadašnji kriterij (udio ukupnog duga manji od 60\% BDP-a).

\section{Grafikon 8.}

Ukupne izravne i potencijalne obveze zemalja članica EU-a, 2013. (u \% BDP-a)

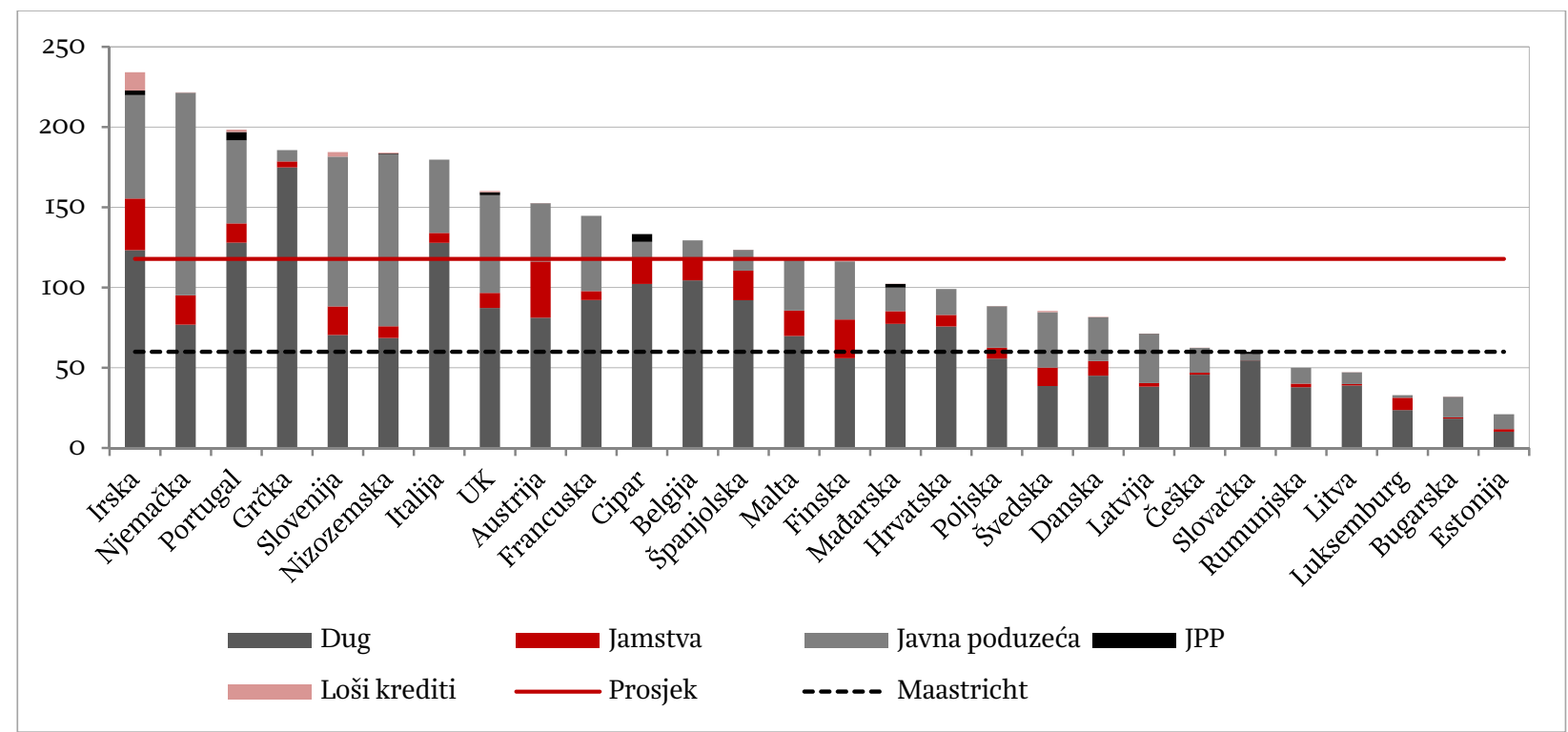

Izvor: Eurostat

Irska i Njemačka gotovo četiri puta premašuju visinu duga utvrđenu kriterijima iz Maastrichta. Do tako jednostavnog zaključka se dolazi već i samim pogledom na ukupne obveze javnog sektora - bez uvida u financijsku imovinu javnog sektora. Ipak, treba imati u vidu da se veći dio obveza u pojedinim državama odnosi na depozite javnih banaka koje su pod kontrolom državes, a koji se u bilanci financijskih institucija bilježe kao obveza, no za potrebe statistike se ne uzima u obzir vrijednost imovine (neto dug). To saznanje dodatno potvrđuje potrebu sagledavanja cjelokupne financijske pozicije javnog sektora prilikom ocjene zaduženosti zemalja. Umjesto na bruto obveze (zbroj svih obveza), države se trebaju fokusirati na neto dug, odnosno na razliku financijskih obveza i financijske imovine. Izračun neto duga trebao bi postati standardni fiskalni pokazatelj kojim bi se postupno nadopunili - sada već prilično zastarjeli - kriteriji iz Maastrichta.

\section{ZAKLJUČAK}

Podaci Eurostata o potencijalnim obvezama država članica EU-a otkrivaju drugačiju sliku izloženosti države fiskalnim rizicima. Oni bi s vremenom mogli izmijeniti i percepciju investitora i rejting agencija te ih navesti na preispitivanje rejtinga pojedinih država što bi se moglo odraziti i na njihove troškove zaduživanja. Ipak, podatke o potencijalnim obvezama u ovom radu valja tumačiti s oprezom iz četiri ključna razloga:

- Podaci su specifični za pojedine države zbog uske povezanosti s njihovom ekonomskom, financijskom i zakonodavnom (pravnom) strukturom.

- Obuhvat podataka nije kompletan za sve država članice, a za pojedine je dvojben (prikazano u tablici u prilogu). To se posebno odnosi na obveze javnih poduzeća koje su teško usporedive, jer su za neke zemlje podaci nepotpuni (ne uključuju obveze financijskih institucija i/ili obveze subjekata koje kontrolira lokalna država).

\footnotetext{
${ }^{5}$ Primjerice, u Nizozemskoj je više od polovine iznosa obveza posljedica nacionalizacije dviju financijskih institucija (2009. i 20I3.).
} 
- Podaci o obvezama javnih poduzeća nisu konsolidirani, pa dio obveza tih poduzeća mogu biti obveze prema povezanim društvima.

- Podaci se odnose na bruto obveze (neovisne o vrijednosti imovine), što je važno za financijske institucije koje imaju značajne iznose imovine i obveza. Uz to, za neke članice, većina se obveza financijskih institucija odnosi na depozite.

Objavljeni podaci Eurostata pokazuju spremnost i posvećenost Europske komisije poboljšanju transparentnosti, povećanju odgovornosti za razborito upravljanje i koordinaciju fiskalnih politika kako među državama članicama tako i na razini EU-a. Otkrivanje potencijalnih obveza hrabar je potez Komisije i država članica koji pokazuje njihovu spremnost da ublaže i eliminiraju buduće potencijalne fiskalne šokove. Objavom obveza, Komisija je otvorila vrata ključnim temama upravljanja fiskalnim rizicima i sprečavanja njihove pojave. Po svemu sudeći, EU će ubuduće sve veću pozornost posvetiti najvećim uzročnicima potencijalnih obveza države - javnim poduzećima i financijskim institucijama u vlasništvu države i poslovnim bankama.

\section{Prilog}

Specifičnosti u dostupnosti podataka za pojedine države članice EU-a

\begin{tabular}{|c|c|}
\hline Država & Nedostatak u podacima \\
\hline Belgija & $\begin{array}{l}\text { Nema podataka o standardiziranim jamstvima. U kontekstu obveza javnih poduzeća, obuhvat lokalnog } \\
\text { sektora nije potpun, a podaci o obvezama poduzeća koja se bave financijama nisu dostupni. }\end{array}$ \\
\hline Danska & Podaci o standardiziranim jamstvima lokalnog sektora nisu dostupni. \\
\hline Njemačka & $\begin{array}{l}\text { Podaci o dugu javnih poduzeća odnose se na 20I2. Značajan dio obveza odnosi se na depozite javnih } \\
\text { banaka koje su pod kontrolom države. }\end{array}$ \\
\hline Irska & $\begin{array}{l}\text { Prilagođena vrijednost kapitala JPP-a izračunata je kao ugovorna vrijednost kapitala umanjena za } \\
\text { izvršene otplate. Podaci za obveze nekih javnih poduzeća odnose se na 2OI2, a općenito uključuju samo } \\
\text { poduzeća pod kontrolom središnje države. U pogledu loših kredita, treba imati na umu da je u obuhvat } \\
\text { opće države 2OII. uključena Irish Bank Resolution Corporation (IBRC). }\end{array}$ \\
\hline Grčka & $\begin{array}{l}\text { Podaci o dugu javnih poduzeća nisu potpuni i obuhvaćaju samo središnju državu te se odnose na } 2012 . \\
\text { Obuhvat nekih društava još se preispituje (s obzirom na potporu koju su primili, još se ne zna treba li ih } \\
\text { klasificirati u opću državu). }\end{array}$ \\
\hline Španjolska & Podaci o standardiziranim jamstvima i o lošim kreditima lokalnog sektora nisu dostupni. \\
\hline Francuska & Podaci o jamstvima dostupni su samo za središnju državu. \\
\hline Hrvatska & Podaci o standardiziranim jamstvima i jamstvima lokalnog sektora nisu dostupni. \\
\hline Italija & $\begin{array}{l}\text { Dio podataka o obvezama javnih poduzeća odnosi se na 20II. i 20I2. Podaci o lošim kreditima nisu } \\
\text { dostupni za lokalni sektor i fondove socijalnog osiguranja. }\end{array}$ \\
\hline Cipar & $\begin{array}{l}\text { Podaci o obvezama javnih poduzeća odnose se na 20I2. Podaci za neka poduzeća nisu dostupni, obveze } \\
\text { javnih poduzeća koja se bave financijama nisu uključene. }\end{array}$ \\
\hline Luxemburg & Obveze javnih poduzeća ne obuhvaćaju obveze javnih poduzeća koja se bave financijama. \\
\hline Malta & $\begin{array}{l}\text { Za JPP je iskazana ugovorna vrijednost. Podaci o obvezama javnih poduzeća ne uključuju javna } \\
\text { poduzeća koja kontrolira lokalni sektor. }\end{array}$ \\
\hline Nizozemska & $\begin{array}{l}\text { Značajan udio obveza javnih poduzeća odnosi se na financijske institucije pod kontrolom države. Više } \\
\text { od polovine iznosa nastao je kao posljedica nacionalizacije dviju financijskih institucija (2009. i 2OI3.). }\end{array}$ \\
\hline Austrija & $\begin{array}{l}\text { Podaci o JPP-u na razini središnje države nisu dostupni. Podaci o obvezama javnih poduzeća uglavnom } \\
\text { se odnose na 2OI2. }\end{array}$ \\
\hline Poljska & $\begin{array}{l}\text { Podaci o standardiziranim jamstvima lokalnog sektora nisu dostupni. Podaci o obvezama javnih poduzeća } \\
\text { ne uključuju podatke za mala poduzeća (primjerice, ona koja zapošljavaju manje od Io radnika). }\end{array}$ \\
\hline Portugal & Podaci o standardiziranim jamstvima nisu dostupni. \\
\hline Slovenija & $\begin{array}{l}\text { Podaci o jamstvima lokalnog sektora nisu dostupni. Većina loših kredita odnosi se na kredite DUTB } \\
\text { banke. Značajan dio obveza javnih poduzeća odnosi se na depozite javnih banaka pod kontrolom države. }\end{array}$ \\
\hline Finska & Podaci o lošim kreditima lokalnog sektora i fondova socijalnog osiguranja nisu dostupni. \\
\hline UK & Podaci za JPP na razini lokalnog sektora nisu dostupni. \\
\hline
\end{tabular}




\section{LITERATURA}

Bundesministerium der Finanzen, 2008. The market for Public-Private Partnership in Germany.

Council Directive 20II/85/EU on requirements for budgetary frameworks of the Member States. Official Journal of the European Union, L 306/4I.

Council Regulation (EC) No 479/2009 on the application of the Protocol on the Excessive Deficit Procedure annexed to the Treaty Establishing the European Community. Official Journal of the European Union, L I45/I.

Council Regulation (EU) No II77/2OII amending Regulation (EC) No I467/97 on speeding up and clarifying the implementation of the excessive deficit procedure. Official Journal of the European Union, L 306/33.

Eurostat, 2015. First time release of data on contingent liabilities and non-performing loans in EU Member States. News release, 26/2015.

Regulation (EU) No II76/2OII of the European Parliament and of the Council on the prevention and correction of macroeconomic imbalances. Official Journal of the European Union, L 306/25.

Regulation (EU) No II75/2OII of the European Parliament and of the Council amending Regulation (EC) No I466/97 on the strengthening of the surveillance of budgetary positions and the surveillance and coordination of economic policies. Official Journal of the European Union, L 306/12.

Regulation (EU) No II74/2OII of the European Parliament and of the Council on enforcement measures to correct excessive macroeconomic imbalances in the euro area. Official Journal of the European Union, L 306/8.

Regulation (EU) No II73/2OII of the European Parliament and of the Council on the effective enforcement of budgetary surveillance in the euro area. Official Journal of the European Union, L 306/I. 